\title{
EM BUSCA DO(s) DEUS(ES) AUSENTE(s): O MODO DE VIDA POPUlista EM LAClaU E EM CHAUI
}

\author{
Benito Eduardo Araujo Maeso ${ }^{1}$
}

\begin{abstract}
Resumo: Entender a política latino-americana passa por precisar suas peculiaridades em relação às formas políticas erroneamente tidas como mais desenvolvidas, em países hegemônicos. Um conceito-chave nesse processo é o de populismo. Para Ernesto Laclau, trata-se de uma técnica política na qual demandas sociais diversas se cristalizam provisoriamente em uma delas ou na figura de um líder, nâo dependendo de alinhamentos ideológicos. Já Marilena Chaui observa afinidades concretas entre práticas populistas e questôes culturais, numa sociedade, tendo foco no chamado "mito fundador" brasileiro e sua presença no imaginário coletivo. Este artigo propōe articulaçōes entre as análises da política latino-americana pelos autores para, a partir disso, ensejar respostas a certas questôes, como: por que o populismo parece se ajustar tão bem à realidade do Sul do mundo? Seria ele mais do que sistema de práticas de governo, mas modo de vida expresso nas instituiçóes políticas, econômicas, sociais e culturais das comunidades latinoamericanas? Até que ponto a busca de alternativas político-intelectuais ao falso Messias - o governante populista - não recai na lógica messiânica que julga combater?
\end{abstract}

Palavras-chave: Populismo. América Latina. Brasil. Laclau. Chaui.

\section{INTRODUÇÁO}

As discussóes sobre o conceito de populismo ocupam papel importante na teoria política, nas últimas décadas, em especial nas análises sobre as formas de governo latino-americanas. Dos populismos "clássicos" (como Getúlio Vargas, no Brasil, e Juan Perón, na Argentina) aos ditos populismos radicais (como Hugo Chávez, na Venezuela, e Evo Morales, na Bolívia), passando

${ }^{1}$ Pesquisador pós-doc no Departamento de Filosofia da FFLCH da Universidade de São Paulo, São Paulo, SP - Brasil. Professor de Filosofia do Instituto Federal do Paraná (IFPR), Curitiba, PR - Brasil. (D) https://orcid.org/0000-0002-4850-0499. E-mail: benito.maeso@ifpr.edu.br.

https://doi.org/10.1590/0101-3173.2021.v44n4.04.p49

\section{(i)}


pelos neopopulismos de Fernando Collor (Brasil) e Alberto Fujimori (Peru), além dos confusos populismos, nos dias de hoje, o continente sul-americano é atravessado por debates sobre a relação entre tais modos de governar, a democracia e as questôes sociais.

Porém, é preciso pensar até que ponto o conceito de populismo está claro, nesses debates. Este artigo busca uma articulação entre as visões de Ernesto Laclau e Marilena Chaui (dois pensadores sul-americanos que vivenciaram experiências populistas, em seus países) sobre o tema, apresentando alguns pontos nos quais seus conceitos se aproximam e outros, onde as divergências teóricas e conceituais explicitam diferenças sobre como cada pensador compreende a própria ideia da política e a construção do tecido social, na América do Sul.

Afinal, o que faz do populismo um regime de afetos políticos que parece se ajustar tão bem à realidade do Sul do mundo? Seria o populismo mais do que um sistema de práticas de governo, mas um modo de vida que se expressa nas instituiçôes políticas, econômicas e sociais - e, por que náo dizer, culturais - das comunidades latino-americanas? Seria ele uma singularidade - ou, num termo caro aos que comparam a realidade brasileira e latina com o restante do mundo, uma "jabuticaba"? Ou os modos de vida populista transcendem fronteiras e têm como cerne uma relação específica entre governantes e governados, passível de se reproduzir mesmo em países "democraticamente maduros" - com toda a ironia do termo? A busca de alternativas políticointelectuais a um suposto autoritarismo intrínseco ao populismo não recairia no messianismo que julga combater, o do falso Messias encarnado no governante populista?

\section{Que RazÃo É ESTA?}

O ponto inicial do pensamento de Laclau é entender características e mecanismos de funcionamento dos processos políticos relacionados ao populismo. Noutras palavras, construir não a definição, mas a teoria do populismo. Este não é estratégia, estilo, ideologia, prática política ou discurso, ainda que tenha em si tais elementos, e conceituá-lo é "[...] uma tarefa complicada e largamente contraproducente" (LACLAU, 2009, p. 51): o objetivo é achar seu elemento constituinte, irredutível a movimentos ou ideologias, para ser pensado como prática. Compreender o populismo é, ao 
fim e ao cabo, "[...] resgatá-lo de sua posição marginal no interior do discurso das ciências sociais." (LACLAU, 2013, p. 55).

Porém, essa busca por uma lógica operacional (não por uma unidade referencial, pois esta seria apenas uma forma de construção do político) significa abdicar de um Sujeito (governante, indivíduo político) que realiza e determina tais práticas, na sociedade. As práticas políticas não expressariam a natureza dos agentes sociais, mas os constituiriam, tendo certa prioridade ontológica. Assim, Laclau (2009, p. 52) assevera:

As práticas seriam unidades de análise mais importantes que o grupo, isto é, o grupo seria o resultado da articulação de práticas sociais. Se este enfoque é correto, poderíamos dizer que um movimento não é populista porque sua política ou ideologia apresenta conteúdos reais identificáveis como populistas, mas porque mostra uma certa lógica de articulação desses conteúdos, sejam eles quais forem.

Logo, pode-se pensar que o termo populismo só é conceituável em articulação com um conjunto de processos sociais que tornam os agentes sociais em seus apêndices. Assim, Laclau apresenta como proposiçóes fundamentais: a) pensar a especificidade do populismo requer sua análise com base em unidades menores do que grupos; b) O significado do populismo não se baseia em conteúdos políticos ou ideológicos presentes na descrição das práticas de grupos, mas em um determinado modo de articulação de tais conteúdos sociais, políticos ou ideológicos²; e c) A forma de articulação produz efeitos que estruturam os modos de representação.

2 Conforme Laclau (2013, p. 53), “[...] o populismo, mais do que uma tosca operação política e ideológica, não seria um ato performático dotado de racionalidade própria, isto é, em determinadas situaçôes a vagueza (da sua definição) não seria precondição para a construçáo de significados políticos relevantes?” É preciso lembrar que um dos principais debates da esquerda até hoje é a pertinência do conceito de classe como sujeito político. Tais questóes (a busca por um projeto político na disputa populismo-socialismo e a busca por um sujeito político na disputa povo-classe) é tensionada por Laclau, com a divisão social entre os campos das relaçóes econômicas e das relaçóes de determinação no campo das superestruturas complexas. É preciso diferenciar o problema da determinação de classe das superestruturas da existência e determinação das classes, nessas superestruturas. Tal distinção é necessária para entender fenômenos como as lutas minoritárias e os engajamentos sociais que não seguem a lógica da luta capital $\mathrm{X}$ trabalho. Os sujeitos políticos possuiriam uma autonomia relativa, em sua constituição. Não é possível condicionar uma redução da classe a uma posição estrutural. Ao mesmo tempo, existem elementos da superestrutura que não são classistas, mas que precisam ser articulados nos processos das lutas sociais. Assim, é preciso pensar nos modos pelos quais os discursos de classe articulam os elementos populistas numa comunidade, grupo ou demanda, outorgando-lhes coerência. 


\subsection{UMA NOVA LÓGICA SOCIAL}

O primeiro fundamento da teoria do populismo é uma teoria do discurso, ou da totalidade estruturada resultante de práticas as quais estabelecem articulaçóes que mudam as identidades dos elementos que as compóem. $\mathrm{O}$ fato de as relaçóes mudarem as identidades dos termos (no caso, dos indivíduos) dá ao discurso o poder de imprimir coerência às práticas e ordem sociais. A individualidade é trespassada pelo social. Somente a partir das práticas político-discursivas no social se pode- aceder à disputa da estruturação da ordem.

Se não são os sujeitos que organizam as estruturas sociais, é preciso ver qual elemento opera no nível intersubjetivo e no estrutural. Laclau apresenta as demandas de indivíduos e grupos como formas elementares e fundantes da construção de vínculos sociais. Demanda é, principalmente, a exigência de algo a alguém - e a busca pela resposta de um Outro instituído. A demanda surge da constatação da falta, do desejo e da alteridade.

As demandas (sejam exigências, sejam pedidos/petiçóes) devem ser dirigidas a uma instância diferente da originária. Seu atendimento e encaminhamento institucional legitimam as cadeias de ordem social, dentro do que Laclau chama de Lógica da diferença, na qual não há divisão social e toda demanda legítima pode ser atendida de um modo administrativo e não antagônico. Porém, o acúmulo de demandas recusadas ou não atendidas criaria laços de solidariedade entre indivíduos e demandas. A lógica agora é a da equivalência, isto é, na qual todas as demandas, apesar de suas diferenças, tendem a reagrupar-se e formar um bloco único e que, simultaneamente, conserva a individualidade de cada elemento.

A ruptura do isomorfismo entre significado e significante permite que este ultrapasse seu conteúdo particular e atraia outros que lhe são heterogêneos, estabelecendo uma cadeia de equivalências e constituindo-se como sua representação. É o que pôde ser visto na convergência das lutas dos movimentos pela terra, pelo trabalho ou por teto - ou na ampliaçáo do escopo de reivindicaçóes iniciada na luta pela mobilidade urbana em direção à profusão caótica de demandas, em 2013. Em ambos os casos, há, de um lado, a sintonia (fabricada por diversas formas de ação política) entre os elementos comuns de tais lutas (o que seria a equivalência) e, do outro, o fato de que, a despeito de suas diferenças, possuem algo em comum: o fato de serem negadas 
pela ordem. Logo, para Laclau, um dos elementos constituintes do processo populista é que

[...] toda mobilização por um objetivo parcial será percebida não somente como relacionada com a reivindicaçáo ou os objetivos concretos dessa luta, mas também como um ato de oposição ao sistema. Esse último fato é o que estabelece o laço entre uma variedade de lutas e mobilizaçóes concretas ou parciais - todas sáo vistas como relacionadas entre si, não porque seus objetivos concretos estejam intrinsecamente ligados, mas porque sáo encaradas como equivalentes em sua confrontaçáo com o regime repressivo. O que estabelece sua unidade não é, por conseguinte, algo positivo que elas partilham, mas negativo: sua oposição a um inimigo comum. (LACLAU, 2011, p. 73).

Pensar o populismo exige a divisão da constituição das demandas e a diferenciação de seus sujeitos. Se aquela é atendida institucionalmente, o sujeito é democrático. Se não é, visto que o sujeito da demanda negada acaba por se perfilar a diversas outras subjetividades, Laclau o denomina sujeito popular. Isso mostra, para o autor, as condiçóes de aparecimento e desaparecimento das subjetividades populares: estas apenas se constituem de forma mais "sólida", ainda que diferencial e mutável, se suas alianças se formam em relação às demandas não atendidas. A ideia de subjetividade popular (e o significante "popular") é tão mais eficaz quanto o sintagma "povo" seja indeterminado, remetendo a significados universais incomensuráveis com o significante.

A construção dos campos de diferenciação e das pontes de equivalências opera simultaneamente ao estabelecimento dos campos nós e eles, ou os de cima e os de baixo. As cadeias de equivalência têm um caráter anti-institucional, pois revelariam a falha no modelo demanda-atendimento entre sociedade (ou grupos) e Estado. Enfatiza Laclau (2009, p. 59):

Para que a cadeia equivalencial crie uma fronteira dentro do social é necessário, de alguma maneira, representar o outro lado da fronteira. Não há populismo sem uma construção discursiva do inimigo: o ancien régime, a oligarquia, o establishment, etc ${ }^{3}$.

\footnotetext{
${ }^{3} \mathrm{Na}$ realidade brasileira atual, esse posto pode ser ocupado por diversos atores, desde os cientistas, médicos, STF, Congresso, ministros, a Esquerda, o Comunismo ou até a cantora Pabllo VIttar. O que importa, nessa lógica, é ter um vetor para cristalizar todo o mal que existe no mundo. Isso parece dialogar com a questão posta por Chaui (1994) de que o populismo brasileiro tem em si um componente messiânico e de luta perpétua entre Bem e Mal, ainda que essa fronteira não seja rígida.
} 
Trata-se de pensar, mais do que a quem o populismo interessa ou quais forças sociais estão presentes em sua dinâmica social, em que medida as relaçóes entre as forças de uma sociedade e sua organização política podem ser avaliadas ou operadas nas formas hegemônicas da política representativa. O populismo começa a ser caracterizado como o momento no qual as identidades coletivas se organizam, de acordo com os campos de diferenciação. Logo, entender o processo de definição do populismo exige interrogar a produção da ordem social, das identidades políticas e o funcionamento da política em si.

Quanto mais amplo o significante e suas cadeias de equivalências, mais frágil o vínculo das demandas particulares. Assim, os significantes da subjetividade popular precisam ser genéricos, para que o desejo particular não se sobreponha ao fluxo geral: a simplicidade dos símbolos populistas é condição para sua eficácia política. ${ }^{4} \mathrm{O}$ populismo parece organizar e construir o social, a partir do rompimento com a ideia de positividade e racionalidade dessa organização. ${ }^{5}$ Logo, não é exceção, mas dimensão e limite constitutivos de toda identidade coletiva. O que o une a esses assuntos é a tentativa de universalização do particular. Exemplo: as construçóes dos significantes "povo" e "poder", em relaçẫo entre si e o segundo como negativo do primeiro, o que os abre à polêmica e redefinição permanentes. No discurso populista, do sintagma povo passa-se ao paradigma povo, às trocas de elementos e demandas em torno desses significantes.

Torna-se possível desmontar o discurso populista, rompendo os vínculos de equivalência, pelo atendimento de demandas particulares (p. ex., a absorção das lutas sociais pelo capitalismo, transformando-as em lutas de consumo) ou a inversão dos signos populistas em seus opostos políticos (p. ex., o uso de bandeiras progressistas por parte da direita radical, como a insatisfaçáo com os padrốes impostos pela Indústria Cultural, apropriada pelos celibatários involuntários - incels). Laclau nota que esse processo representa uma luta por hegemonia, e define esta como "[...] a operação de assumir, por meio de uma particularidade, um significado universal incomensurável.” (2013, p. 120). As demandas adquirem autonomia parcial e transitória: tal inversão é efeito de o populismo ser um princípio formal de articulação dos conteúdos políticos.

\footnotetext{
${ }^{4}$ Como o nome do líder, o gestual, a camisa do time, as palavras de ordem.

5 Sobre essa ideia é que se constituiu todo um ramo de análise do fenômeno populista, o qual o trata como uma forma irracional ou primitiva de atividade política, eminentemente pulsional e, por isso, afastada do ideal racional-iluminista do que seria a Política. Porém, é complicado e ingênuo imaginar que o processo político seja, em sua totalidade, apenas a expressão do Racional.
} 


\subsection{O POPULISMO COMO A LÓGICA DA POLÍTICA OU DO POLÍTICO?}

O populismo surge como elemento intrínseco e constitutivo tanto da política (mecanismos e formas que criam uma ordem de vida comum) como do político (o estado das relaçóes entre as existências humanas e que se expressa na diversidade das relaçôes sociais; o que é a essência da política e seu marco conceitual). Essa diferenciação é importante, pois a lógica de equivalência pode operar em qualquer lugar da estrutura socioinstitucional. $\mathrm{O}$ populismo não define a política concreta de instituiçôes ou movimentos, mas funciona como meio de articulação de seus temas. Logo, "[...] deveríamos nos perguntar o seguinte: até que ponto um movimento é populista?” (LACLAU, 2009, p. 66).

Porém, é possível a sinonímia total entre populismo e política, ou uma identificação na qual toda intervenção política é, até certo ponto, populista? Qual a fronteira social construída que mobiliza o povo contra um inimigo? O que diferencia a lógica populista das demais e qual seu lugar, no campo político? Laclau nota que a construção de sociedade exige movimentos retóricos. Assim, como o populismo tem na retórica um elemento operativo, ele não apenas explica esse processo social, como é seu componente constitutivo. A vagueza ${ }^{6}$ do discurso populista não é um defeito, mas característica relevante que, por vezes, aparece na própria realidade social. A dimensão e poder do discurso populista variam com a distância entre projetos e alternativas políticas, o que significa que todo ato social é entremeado por essa lógica. Assinala Laclau (2013, p. 228):

Isto quer dizer que o político tornou-se sinônimo de populismo? Sim no sentido que eu concebo este último conceito. Uma vez que a construção do 'povo' é um ato político par excellence, em oposição a uma pura administração de um quadro institucional estável.

O populismo questionaria a ordem institucional pela construção do povo como agente histórico, ou seja, a construção de um Outro. Depreendese que, então, nenhum regime verdadeiramente político pode abdicar de uma contradição interna, de um tipo de divisão social. Em Laclau, um regime

\footnotetext{
${ }^{6}$ Nas palavras do próprio Laclau, “[...] não seria essa lógica de simplificação e de tornar alguns termos imprecisos o que constitui a própria condição da ação política?” (LACLAU, 2013, p. 54).
} 
que busque ou que obtenha homogeneidade entre a comunidade e a vontade expressa por essa comunidade seria, por definição, totalitário. ${ }^{7}$

\subsection{A TENSÁO INTERNA DO POPULISMO LACLAUNIANO}

Todo totalitarismo seria, para Laclau, a tentativa de anular as divisóes sociais que caracterizam a política, pois qualquer setor numa sociedade sempre terá o ímpeto e o direito de reivindicação, o que significa estabelecer as linhas de divisão que marcam tanto o populismo como a política e o político. Logo, o conceito de povo que norteia o populismo e baliza a democracia surge da impossibilidade do sujeito político universal. $\mathrm{O}$ povo não expressa uma identidade originária: ele a constitui (tanto o povo como o discurso populista, que é o discurso que forma o conceito em si). As relaçóes de representação (entre demandas particulares e postulaçóes universais) seriam o terreno no qual o social se forma. Nenhum sistema totalitário realmente é "popular", na acepção da palavra aqui empregada, porque náo é calcado na diferença:

[...] a construçáo de um povo é a condição sine qua non do funcionamento da democracia. [...] Se acrescentarmos a isso que o "povo", conforme vimos, não está essencialmente ligado a qualquer matriz simbólica particular, então teremos abarcado o problema do populismo contemporâneo em todas as suas dimensốes. (LACLAU, 2013, p. 246).

Pensar o populismo como lógica de construção de sujeitos políticos significa pensar como se dá a constituição do povo, ou como se dá a formação de uma identidade coletiva como agente histórico. A pluralidade do social, com a multiplicidade de posiçóes e demandas que se seguem às lutas particulares e a expansão do imaginário democrático-igualitário, é o resultado histórico e contingente das articulaçôes de subordinação (de classe, gênero, etnia, cultura, sexualidade etc.) que ocorrem na sociedade.

\footnotetext{
7 Mas ainda há problemas em relação a uma democracia radical. Se as primeiras abordagens de Laclau tentavam pontos de contato entre a razão populista e uma possível radicalização da democracia, pensá-la só como lógica pode significar lê-la como limitadora dessa radicalização. Se os agenciamentos pelas demandas ameaçam as condiçôes necessárias para pactos sociais que permitam aprofundar a democracia, os regimes populistas, independentemente do espectro político, poderiam sempre tender a incorporar elementos autoritários em sua prática, de acordo com o agenciamento que ocorra. Nenhum desses devires precisa ser intrinsecamente democrático ou progressista. Democracia radical, para existir, exige o fim do capitalismo como conhecido. Porém, não apenas as demandas podem se cristalizar exigindo seu fim, como também exigindo a radicalização e o aprofundamento desse sistema, processo que se observa em diversos países da América Latina.
} 
$\mathrm{O}$ autor argentino não renuncia à noção marxiana de classe como agente histórico, mas a retira do centro da operação social. A questão passaria a ser "[...] até que ponto os enfrentamentos coletivos que constroem a unidade das posiçôes do sujeito dos agentes sociais constituem a estes como classes." (LACLAU apud RETAMOZO, 2017, p. 170). Na teoria laclauniana, tal resposta mudaria com as circunstâncias ou com as relaçóes que se formam, a cada caso:

Em termos práticos, reportando-nos a um exemplo anterior, não existe motivo pelo qual conflitos que ocorrem nas relaçóes de produção deveriam ser os pontos privilegiados de uma luta anticapitalista global. Um capitalismo global cria inúmeros pontos de ruptura e antagonismo - crises ecológicas, desequilíbrio entre diferentes setores da economia, desemprego em massa etc. -, e somente uma sobredeterminação dessa pluralidade antagônica pode criar sujeitos anticapitalistas globais capazes de levar adiante uma luta digna desse nome. E, conforme demonstra toda experiência histórica, é impossível determinar a priori quem serão os atores hegemônicos nessa luta. Não está claro, de modo algum, que eles serão os trabalhadores. Tudo o que sabemos é que eles serão aqueles que estarão fora do sistema, os excluídos, aqueles a quem denominamos os heterogêneos, decisivos no estabelecimento de uma fronteira antagônica. (LACLAU, 2013, p. 223).

Todavia, falar de subordinação não implica deduzir resistências e antagonismos a partir de relaçôes de poder: as resistências só se articulam num processo de dupla construção, na qual a resistência constrói e é construída pelos agentes sociais. ${ }^{8}$ As formas múltiplas de articulação da ordem social (capital, neoliberalismo, patriarcado, racismo etc.) não produzem necessariamente resistências. Não que os agentes e sujeitos das lutas não sejam vítimas de opressão e sofrimento, mas a caracterização de uma situação como injusta e ilegítima exige a produção de um discurso que construa essas situaçóes como tais. O desafio é pensar como as posiçóes de subordinação configuram-se em espaços de subjetivação e antagonismo. As definiçóes de injustiça ou ilegitimidade não são transcendentes, e construir os critérios que

${ }^{8}$ Essa relação bi-imbricada de agentes sociais que opera no próprio corpo social é aquilo que Gramsci chama de crise orgânica de representaçấo e hegemonia. A crescente incapacidade do sistema social em absorver demandas institucionais e sociais dá espaço às cadeias de equivalência que acabam por colocar-se como antagonistas entre si e em relação ao próprio sistema, ao qual, no fundo, devem sua existência. O sujeito político se constrói pela interaçáo entre os processos de subjetivação política e a emergência prática da luta pelas demandas. 
fundamentem tais definiçóes - o que define os papéis de nós e eles, no processo - torna-se uma tarefa política por excelência.

A teoria de Laclau tem como um de seus pilares a ideia da construção discursiva do sujeito-povo, mas isso não se dá como linguagem pura ou apela a uma ideia de um povo homogêneo. Não é possível pensar num discurso externo às práticas sociais nem na constituição dos sujeitos, sem um processo de identificação e a disposição para a ação. Não se trata de jogo discursivo, contudo, de constatar que a produção do sujeito também sofre influência das paixões e dos afetos. O processo das demandas é um processo de engajamento que se dá parte racional, parte emocionalmente entre os componentes do grupo.

Assim, ver o populismo como lógica política evita que ele seja associado a um conteúdo ideológico particular ou a resultados político-práticos específicos. Impede, também, uma correspondência única entre subjetividade política e processo populista: de acordo com as subjetividades invocadas ou constituídas, as condiçóes históricas e as relaçôes estabelecidas, o sujeito político pode ser transformador, excludente ou combinar essas naturezas em proporçóes múltiplas. Ou seja, o populismo requer que discursos (palavras, imagens, símbolos, alegorias) se sedimentem em práticas, instituições e identidades. A figura do líder catalisa o processo, mas ele mesmo se torna substituível, a partir do momento em que não é mais vetor das demandas, instáveis por definição. Ressalta Laclau (apud RETAMOZO, 2017, p. 178):

$\mathrm{O}$ antagonismo potencial entre demandas contraditórias pode explodir a qualquer momento; por outro lado, um amor pelo líder que não se cristaliza em nenhuma forma de regularidade institucional - ou em termos psicanalíticos, um Eu ideal que não é internalizado parcialmente pelos Eus correntes só pode resultar em identidades populares efêmeras.

\section{TeOPOPULISMO À BRASILEIRA}

Marilena Chaui também observa, assim como Laclau, que uma das características intrínsecas ao populismo é a eliminação das mediaçóes entre governantes e governados, mas vê a questão do alinhamento ou não das demandas de grupos - e sua cristalização em vetores diversos, como slogans ou líderes - mais como efeito do que causa do processo populista. Pensar a dinâmica de instauração de uma política populista apenas no prisma laclauniano deixaria de lado, na visão da filósofa, todo o processo ideológico- 
cultural que constitui os laços e as tensóes dentro de uma sociedade, reduzindo o populismo a um estágio ou técnica de fazer política.

No caso brasileiro, em especial, a autora vê o populismo como a materialização do processo da teologia política ${ }^{9}$ brasileira, cuja base é a instauração de um mito fundador calcado no par conceitual e histórico entre providencialismo e messianismo. As raízes teológicas da cultura política brasileira - e, por extensão, das produçóes sociais, intelectuais e artísticas são especialmente visíveis nas narrativas do Brasil como a Terra Prometida, a-histórica e pertencente ao reino da Natureza (o "gigante" e o "paraíso"), cujo regente é o escolhido pela divindade para salvar o povo devoto. $\mathrm{O}$ governante, nomeado pelo Alto, pode ser tanto o redentor ansiosamente esperado como a provação final antes do grande arrebatamento. Um lugar onde o tempo não flui, preso a um eterno Agora, desde a carta de Pero Vaz até a promessa de sermos o país "do futuro", repetindo a narrativa da Canaá hebraica, da Idade de Ouro. O Brasil é a dimensão material da ideologia de um retorno a uma utopia.

O mito fundador possui "[...] dimensóes antropológica e psicanalítica, impondo um vínculo interno com o passado como origem, isto é, com um passado que não cessa, que não permite o trabalho da diferença temporal, e se conserva perenemente presente." ( CHAUI, 1994, p. 3). ${ }^{10}$ De forma similar ao processo do recalque, tal passado acaba por repetir-se continuamente, moldando-se às dinâmicas do presente e encontrando "[...] novos meios para exprimir-se, novas linguagens, novos valores e ideias, de tal modo que, quanto mais parece ser outra coisa, tanto mais é a repetição de si mesmo." ( CHAUI,

9 Essa expressão é mobilizada em uma perspectiva Chauiniana, com base nos elementos da análise de Espinosa, no Tratado Teológico-Político, texto no qual o autor hispano-holandês busca mostrar que, a partir da Modernidade, construir estruturas políticas com elementos fundantes que emulem processos e fatores religiosos é, em si, incoerente, violento e aberrante. Se definirmos teologia como interpretação das Escrituras ou de livros sagrados, Chaui (2003) observa que esse processo é, por definição, um exercício de poder, ao estabelecer um conceito prévio de Verdade. Logo, toda teologia é política. Todavia, ao assumirmos que um dos pilares de uma sociedade republicana e democrática é a separação prática entre religiāo como vida privada e política como vida pública, a presença da teologia como elemento constitutivo de estruturas de poder é, no mínimo, um equívoco. Um exemplo histórico é trazido por Espinosa, ao comparar o estado teocrático hebreu, localizado no tempo e no qual a religião exercia o papel de código de leis, e a religião cristã - caracterizada pela interioridade. Se esta se liga com a política, como no caso dos reis ungidos pelo papa, deixa de ser cristianismo. Uma república necessita dessa separação público-privado, mas, no Brasil, tal associação nunca foi completamente desfeita assim como em outros países da América. Logo, nunca fomos uma república de forma completa.

${ }^{10}$ A numeração das páginas deste texto de Chaui seguirá a do arquivo original compartilhado pela filósofa com o autor do texto, pois a edição original está esgotada e não é possível ir a uma biblioteca física, devido à quarentena. 
1994, p. 3). Um exemplo desse movimento circular está na própria bandeira brasileira, cujo lema positivista, no fundo, tem como mensagem que "[...] é preciso que haja ordem para que exista progresso, mas esse mesmo progresso só pode se dar em respeito à ordem estabelecida." (SIVIERO, 2019, p. 5).

É necessário lembrar que não há a possibilidade, nesta natureza-paraíso denominada Brasil, de um pacto social aos moldes hobbesianos, quando a política nasce como filha do medo. Neste grande "oriente" 11 , não há sociedade, apenas "povo" e Escolhido. Assinala Chaui (1994, p. 7-8):

Um elemento essencial nessa perspectiva do milênio é a figura do combatente que prepara o caminho de Cristo: recebendo nomes variados, como Papa Angélico, Imperador dos Últimos Dias, o Encoberto, o Encantado (denominaçóes dadas, por exemplo, a D. Sebastiáo e retomadas por Antônio Conselheiro, entre outros), o pré-salvador surge nas vestes do dirigente messiânico em quem são depositadas todas e as últimas esperanças.

Esse conjunto de ideias opera admiravelmente como ferramenta de pacificação social, ainda que por certo tempo, pois favorece a divisão clara do tecido social em dois campos: aos de cima, os privilégios "em vida" estão justificados por náo haver conflito ético ou moral em receber todas as benesses de uma só vez, no paraíso atemporal, pouco importando se, na mesma população, um imenso contingente de pessoas sequer pode sonhar com o momento de receberem a Graça. Para o restante da população, vale a lógica de que, quanto maior a tribulação, maior a recompensa posterior até a chegada do momento em que finalmente seria permitida, a esse povo, a entrada no Paraíso. Ocorre o amálgama entre a narrativa da Providência, a da pátria amada Mãe Gentil (local do genos, do clã, e não da coisa pública) que JÁ É um Paraíso na Terra, e o Messianismo baseado em Joaquim de Fiori, quando, após uma era de tribulaçóes, surgirá o reino de mil anos que antecede a chegada do Céu na Terra. Como Chaui (1994, p. 7) observa,

\footnotetext{
${ }^{11}$ Oriente, na referência realçada pela autora, é um símbolo presente na correspondência dos invasores da América, tanto navegantes como evangelizadores, representando tanto o que é distante (Japão, China e locais com os quais os navegadores ambicionam estabelecer comércio) como uma alegoria do Jardim do Éden. Afirma Chaui (1994, p. 4): "A Bíblia, no livro da Gênese, afirma que o paraíso terrestre, que seria de leite e mel e cortado por quatro rios que atravessam toda a terra, localiza-se no Oriente. A partir do relato bíblico, as grandes profecias, particularmente as de Isaías e Daniel, descreveram com detalhes o oriente-paraíso, terra cortada por rios cujos leitos são de ouro e prata, por onde correm leite e mel, em cujas montanhas derramam-se pedras preciosas, habitado por gentes belas, indómitas, doces e inocentes como no Dia da Criação, promessa de felicidade perene e redenção."
} 
[...] há a divisão do tempo em três eras - do Pai, do Filho e do Espírito Santo [...] e o embate final entre o Anticristo e Cristo, durante a era messiânica, com a vitória de Cristo e a instalação de um Reino de Mil Anos de Felicidade, tempo do fim e fim dos tempos, que prepara o Juízo Final e a instauração do Reino Celeste de Deus na terra, para sempre.

Nesse Brasil imaginado e imaginário, não há distinção alguma entre esferas pública e privada: se o "povo abençoado" tem o "rei justo" escolhido por Deus, o fundamento do pensamento, do locus e da práxis republicanas - a convivência mediada entre diferenças - é impossível de existir. Tal concepção de mundo só pode gerar uma autocracia. Ao mesmo tempo, resulta em modos de vida, comportamentos e açóes devotas por parte do povo, porque exige que este se prepare, pela obediência, pelo ascetismo e pela provação, para o tempo do fim. O messias chega, quando o povo estiver pronto, ou seja, no máximo de seu sofrimento constante.

\subsection{As CARACTERÍSTICAS DO LÍDER POPULISTA}

Os elementos desse messianismo à brasileira sempre estiveram difusos e latentes, na sociedade, manifestados no que a autora chama de poder autocrático: o poder nas relaçóes pessoais exercido como tutela sobre o Outro e o clientelismo derivado disso, o poder sem mediaçóes cristalizado no Escolhido, a satanização ou a divinização da figura de liderança e a imbricação entre estrutura familiar e estrutura político-social, mantendo o poder parental, permeados pelo mito fundador de uma sociedade paradisíaca e fora da História. O governante é o Pai (como Vargas) e a sociedade é uma família, a qual, apesar de seus conflitos, deveria, em tese, manter-se unida e obediente ao pai, nem que seja pela força (ou pelo poder repressor do Estado). Logo, não há classes ou qualquer estrutura social que seja agente de conflito, apenas o mascaramento ideológico da realidade de exploração social.

Tais características do poder autocrático se ajustam admiravelmente, tanto com o discurso religioso que impera no país (seja católico, seja evangélico neopentecostal, ambos conservam as características messiânicas) quanto com o discurso de eficiência e rentabilidade na gestão do Estado, das relaçôes sociais e pessoais, motto do neoliberalismo. Além disso, há uma retroalimentação entre esses fatores, que serão melhor destrinchados agora: 
a) O poder sem mediaçóes busca demolir as instituiçôes e a estrutura de organizaçáo do Estado, para garantir a prevalência do Poder Executivo sobre os demais, transformando o ocupante desse cargo em legislador e magistrado. Sem mediaçôes ou instâncias entre sociedade e governante, suas decisões ganham imediatamente o status de "vontade do povo" (um "povo" abstrato e uma "vontade" esvaziada de seu significado), e toda arbitrariedade está não só autorizada, como também legitimada.

b) O poder enquanto tutela e favor se caracteriza como um tipo de política "[...] em que o governante se apresenta como aquele que detém não só o poder, mas também o saber sobre o social e sobre a lei (o significado da lei) e, portanto, priva os governados do conhecimento do mundo sociopolítico, podendo, assim tutelá-los.” ( CHAUI, 1994, p. 1). Sem mediaçôes, o governo não mais atende a reivindicações ou concilia conflitos, mas cede favores e monta clientela. Trata-se de tecnocracia: o governo se torna prestador de serviços, que antes eram direitos adquiridos e institucionalizados, podendo controlar a bel-prazer a sua aplicação, o que inclui as próprias leis. A prática do lawfare, um uso discricionário da lei, também é um elemento desse tipo de poder.

c) O poder parental, que opera "[...] simultaneamente com a transcendência e a imanência.” ( CHAUI, 1994, p. 3). O governante apresenta-se como fora do social, mas somente pode agir estando inserido na sociedade, já que seu poder se dá sem mediaçóes institucionais. O triunfo da vontade do chefe do clâ, grupo ou milícia. Um bom exemplo são os candidatos que se colocam contra o establishment, porém construíram suas carreiras dentro do sistema, reforçando-o.

d) O poder carismático surge no momento em que o próprio poder e seu ocupante não possuem mais distinção. Nesse caso, o poder necessariamente é despótico, pois é outorgado ao governante por Deus, que é onipotente. Conforme Chaui (1994, p. 2),

[...] o poder encontra-se total e plenamente ocupado pelo governante, que o preenche com sua pessoa porque esta se identifica com o corpo do detentor do poder e com o próprio lugar do poder. O governante populista encarna e incorpora o poder, que não mais se separa nem se distingue de sua pessoa, uma vez que náo se funda em instituiçóes públicas nem se realiza através de mediaçôes sociopolíticas. 
A figura do governante ou do Soberano ganha uma dimensão jurídicoteocêntrica e uma dupla natureza, a qual concilia o humano e o divino. A lei aplicada por ele é a vontade divina, o que o torna em aparência igual ao povo, mas tem uma natureza mista de humano e divino. O soberano se arvora de símbolos messiânicos e, não sendo uma entidade criada pelo contrato, desde o início exprime a separação total entre Deus e Seu povo. São duas as formulaçóes possíveis dessa figura, para Chaui (1994, p. 8-9):

A primeira delas, fundada em Santo Agostinho, afirma que, pelo pecado, o homem perdeu todos os direitos e, portanto, perdeu o direito ao poder. Esse pertence exclusivamente a Deus. [...] A segunda fonte jurídicoteocêntrica, sem abandonar a noçáa de favor, introduz a ideia de que o governante representa Deus porque possui uma natureza mista como a de Jesus Cristo. O governante possui dois corpos: o corpo empírico, mortal, humano, e o corpo político, místico, eterno, imortal, divino. Por receber o corpo político, o governante recebe a marca própria do poder: a vontade pessoal absoluta divina.

No caso brasileiro, que poderia ser de certa forma expandido a outras culturas, essas formulaçóes embasam a ideia do favor como elemento motriz das relaçóes sociais. Aqui, favor significa o abandono de princípios, como o da isonomia, em benefício dos critérios de escolha pessoal e os caprichos do representante divino. Os favores concedidos pelo governante (das nomeaçóes de cargos às políticas assistencialistas) são dádivas, tais como os dons do Espírito Santo, ocultas em um vocabulário dúbio, como o "mérito" ou o "prêmio", os quais apontam para a confluência entre o ascetismo e o esforço individual com a Vontade do outorgante.

A autora observa a curiosa etimologia do termo populismo: o radical populus refere-se exatamente a quem fica fora da equação de poder enunciada pela palavra. No fundo, pode-se pensar que o próprio conceito de povo é o significante vazio ao qual Laclau alude, e não as palavras de ordem das demandas. Assim como o corpo duplo do governante, há uma cisão entre o singular e o geral: enquanto o "povo", massa indistinta de governados, é geral, os favores são concedidos a singulares e particulares.

O próprio processo eleitoral acaba por reproduzir tal lógica: se a voz do povo é a voz de Deus, a escolha das urnas não é a vontade da população, mas a expressão da vontade divina. O líder populista é legitimado e normalizado (ainda que de forma ideológica, por um simulacro de processo eleitoral). $\mathrm{O}$ 
mito fundador alimenta, no presente, a face autoritária do poder, ao reforçar a natureza divina do governante. A ideologia retroalimenta, via passado mítico, a manutenção das imagens míticas que permitem o controle político e a própria estrutura organizativa da sociedade brasileira, autoritária, violenta, antidemocrática, hierarquizada e desigual: “[...] a estrutura e organização da sociedade brasileira reitera, alimenta e repete a mitologia, porque este é um dos fundamentos da própria forma assumida por nossa sociedade." ( CHAUI, 1994, p. 10).

\subsection{O Dilema DAS RELAÇÓES SOCIAIS NO BRASIL E O NEOLIBERALISMO COMO VONTADE DE DeUS}

O amálgama entre a lógica do favor, as relaçôes clientelistas e a rígida hierarquia social mascarada pela ideologia da Pátria Amada Mãe Gentil e do governante Pai de seus filhos (o povo) instaura a polarização entre mando e obediência nas relaçóes pessoais e sociais brasileiras (a frase "manda quem pode, obedece quem tem juízo" é lapidar, nesse sentido). Como nunca ocorreu completamente a abolição do poder divino em prol do poder social secular, o triedro mito fundador, governante divinizado e ausência de História gera, para Chaui (1994, p. 10), a

[...] impossibilidade de efetuar a ideia liberal da política como pacto ou contrato (pois a condição do contrato é a igualdade entre as partes); impossibilidade de realizar a política democrática baseada nas ideias de cidadania e representação - esta é substituída pelo favor, pela clientela, pela tutela, pela cooptaçáo ou pelo pedagogismo vanguardista; impossibilidade de visualizar a ideia socialista de justiça social, liberdade e felicidade.

A alternativa de uma democracia plena, a qual pode barrar o clientelismo e o autoritarismo, encontra-se bloqueada, nesse quadro, pela articulação entre um regime semiteocrático a uma democracia imperfeita (tutelada pelo capital financeiro e por uma estrutura oligárquica) e um neoliberalismo de fachada (com discurso liberal e prática cartelizantes). Chaui utiliza a filosofia de Lefort para apontar que a desintegração das diferenciaçóes entre poder e lei, lei e saber social e poder e governante se desfazem, acarretando o preenchimento das instâncias de poder e a identificação plena entre a máquina do Estado e o corpo governante que a opera. 
Chaui acompanha o pensamento lefortiano de que a democracia é, antes de tudo, formação social. A democracia nasce, quando se apaga a transcendência de fundamento do poder, no processo de desincorporaçáo do poder: a distinção entre lugar do poder e o exercício da autoridade. $\mathrm{O}$ poder democrático é um lugar sempre vazio, porque não há uma comunidade orgânica, indivisa e unificada que seja sua expressão. Ninguém pode enunciar o discurso do poder (discurso em bloco): a sociedade É divisão. E é dessa divisão que a ideologia nasce, porque se produzem discursos que expressam e salientam essa divisão. Ontologicamente, o ser do político abre uma dialética entre o desejo positivo dos grandes e a negativa dos pequenos - o conflito. Este é uma dialética sem síntese.

O sentido do poder não se esgota nas instituiçôes: a própria dimensão simbólica do poder pôe seu negativo, sua unificaçẫo imaginária em ação. Mas persiste o desejo excessivo de atribuir ao poder a transubstanciação da divisão social. O totalitarismo é um efeito possível da recusa da indeterminação democrática, é a realização imaginária dolorosa da concretização do desejo de união social.

Porém, o autoritarismo populista social brasileiro se constitui a partir de formas bem definidas: o privilégio e a carência. Por exemplo, a miséria é o que se tem de pagar aqui até a chegada do profeta e depois de Cristo. $\mathrm{O}$ que o povo busca não é poder, mas sim justiça e felicidade: a alegria do retorno ao paraíso perdido. Para a classe dominante, embebida na ideologia providencialista, o poder é seu direito natural, legitimado no ufanismo e no patriotismo; no rumo para o destino manifesto há, de um lado, a carência absoluta do povo, o qual necessita até do mínimo possível para sobreviver e, do outro, o privilégio absoluto, que detém todo o poder e influência política e econômica sobre a massa dos desprivilegiados.

A forma do privilégio é visível nas oligarquias existentes no meio do capitalismo brasileiro, voltadas para a manutenção e expansão do particular. Os objetos e fatos sociais não podem virar direitos, pois deixariam de ser privilégios. Dialeticamente, as carências da sociedade seguem a mesma relação, o que determina, por exemplo, a violência da repressão da luta por direitos sociais, no país. O evento social não pode deixar de ser privilégio ou carência. Dessa maneira, o autoritarismo se sustenta, uma vez que, ao fazer política, o grupo privilegiado apenas cria instâncias e mecanismos que reforçam, reformam (no sentido de se adaptar a contingências e novas demandas), incrementam seu poder: "[...] a carência (popular) espera ser preenchida e 
suprida pelo governante; o privilégio (dominante) espera ser conservado pelos favores do governante." ( CHAUI, 1994, p. 11).

Por repetir o mecanismo populista de diversas formas, o Brasil é lugar especialmente frutífero para o neoliberalismo, o qual operará como uma ideologia das ideologias que justificam o processo: o encolhimento do espaço público e o aumento do espaço privado alimentam a matriz teológica do poder, por meio de espetáculos e simulacros de cidadania e política. Chaui (1994, p. 12) interroga:

$\mathrm{O}$ que pode favorecer melhor uma matriz teológico-personalista do poder do que uma ideologia do tipo neoliberal? A ideologia neoliberal alimenta tudo aquilo que está presente na matriz teocrática e na matriz teológica do poder, isto é, a noção de personalidade e subjetividade como centro do poder, a indiferenciaçáo entre público e privado, o narcisismo do governante, a política com espetáculo, mistério, transcendência e saber acessível somente aos iniciados, os competentes.

É característica fulcral do funcionamento da economia neoliberal que os trabalhadores sejam penalizados pela fragmentação da produção, a obsolescência das qualificaçóes, o desemprego estrutural e o desmanche dos referenciais sociais, da ação e do trabalho, criando uma atmosfera constante de humilhação, opressão e injustiça. Esse ethos acabaria, baseando-se no pensamento de Chaui, por permitir a ascensão de um conjunto ideológico milenarista, pois as classes populares, alijadas dos referenciais de segurança social, somente encontram segurança no Deus Mercado. As noçóes de Graça, Redenção e Salvação ganham um novo léxico e metamorfoseiam-se em certas imagens, como as do "empreendedor de si", o "vencedor", a "meritocracia", a "livre concorrência", a "competição" e outras de mesmo jaez. A teopolítica populista à brasileira apropria-se da onipotência divina e a aplica, como em uma aposta, no "candidato mais bem posicionado para ganhar", na divisão constante das relaçóes sociais (reunidas somente pela fé) e no mercado financeiro. Em comum, as palavras desses seres imaginários são tomadas como verdades absolutas e incontestáveis.

\section{Modos de POlítica, MOdos DE VIDA: AS INSTITUIÇóes NÁO FUNCIONAM NORMALMENTE}

Ao olharmos mais de perto as estruturas teóricas apresentadas pelos dois pensadores, certas questôes parecem exigir mais atenção, principalmente 
ao aplicarmos suas lógicas à análise do fenômeno populista, na América Latina. Se é possível ver uma aproximação conceitual entre eles, ao observarem o populismo como o apagamento das estruturas de mediação nas relaçóes entre o povo e o líder - e esse ponto, em específico, é fulcral em ambos os conceitos de populismo dos autores -, a diferença existente nas formas pelas quais esse apagamento ocorre nos leva a refletir sobre a dinâmica interna entre populismo e democracia.

Ao se pensar o populismo como teoria da configuração do sujeito político, é preciso pensar que seu modus operandi, segundo Laclau, estabelece o momento instituinte e destituinte do político, de cristalização e dissolução de relaçôes e sistemas sociais, o que impacta na definição do que é a política, a qual passa a ser a instância da administração desses processos. Já os sujeitos políticos, originados parte dentro da ordem, parte às suas margens, seriam os agentes capazes de questionar a ordem e construir a legitimidade das transformações sociais. Porém, qual o alcance dessa postulação?

Para Laclau, o populismo é elemento constitutivo inclusive do processo democrático, ainda que recaindo por vezes em momentos de desejo ou prática de ruptura da dita institucionalidade. Bastaria, por conseguinte, um funcionamento institucional eficaz, com o atendimento das demandas latentes em uma sociedade, para termos um antídoto contra a tentação autoritária da qual o populismo, de maneira geral, é tantas vezes acusado? A História demonstra que não. Corre-se o risco permanente de que, pelo fato de esse mecanismo de representação política abranger simultaneamente representantes e representados, náo existindo vontade geral ou essência coletiva transcendente a esses agentes, haja certa dificuldade no estabelecimento de qualquer limite ou subordinação alheia a seus próprios ditames, por não ser evidente a quais vontades ou interesses os representantes devem se submeter ou que tipo de controle a população pode e deve exercer sobre eles. O critério que define o valor da legitimidade da razão populista estaria restrito à representação particular da célula líder-seguidores. Se há uma dimensão produtiva nisso, também se corre o risco de que o líder, supondo ou crendo ter uma identidade substantiva com a população, acabe por afastar-se cada vez mais dela, agindo em seu nome como bem quiser.

Esta é uma preocupação evidente na teoria de Chaui que não parece encontrar correspondência no autor argentino. Para ela, com base em Espinosa, o cerne teológico-político que move o populismo é incompatível com a democracia ou com o republicanismo (ainda que estes, evidentemente, 
não sejam sinônimos). Segundo a autora, em uma dinâmica populista, não há institucionalidade pressuposta, pois esta é um corpo estranho às relaçóes entre o Alto e o Baixo. No exemplo brasileiro, tão importante para nós, a política populista sequestra a estrutura institucional - pela prática do favor -, mas simultaneamente a compóe desde a origem e a utiliza para sua perpetuaçáo, inclusive quando os sujeitos driblam a instituição, por meio da concessão de tais favores, ou quando a instituição se torna o centro de tal distribuição.

Ambas as teorias parecem funcionar de modo dialético, em muitos momentos, apesar de suas discordâncias. Se Laclau busca por certa universalização metodológica do populismo, a qual só existe com um conjunto de práticas político-discursivas que constroem o sujeito popular, sendo precondição para o surgimento desse de acordo com Chaui, a fronteira "bem X mal” - ou, por equivalência, a definição entre nós e eles, postulada por Laclau - já estaria esboçada a partir do momento em que a narrativa messiânica, presente desde a invasão do continente, começa a ser elemento constitutivo da própria noção do que é a América Latina, com sua narrativa cunhada, desde o princípio, pela divisão entre Luz e Trevas, herdada de portugueses e espanhóis.

Ainda para Laclau, a lógica desta divisão social é estabelecida pela criação de uma cadeia de equivalências entre uma série de demandas particulares. Há similaridades com a forma de aglutinaçáo discursivo-social levantada pela pensadora brasileira, sendo este um ponto, digamos, operacional na metodologia populista. Porém, a criação dessa cadeia pode dar-se em um terreno fundamentalmente ideológico, embora não necessariamente vinculado a questóes de classe. Fatores como controle de narrativas e mídia não podem ser ignorados, na formação da cadeia de equivalências, a qual corre sempre o risco de não ser equivalente, já que o jogo de forças de uma sociedade - relaçóes políticas, econômicas, religiosas, culturais, etc. - direcionaria o sentido dessa cadeia. Nesse sentido, Chaui reforça que a prática populista seria um meio de manutenção e aprofundamento do poder das classes, que, tradicionalmente, já comandam a realidade brasileira e sul-americana.

Como essas equivalências somente ocorreriam e se consolidariam pela emergência de um elemento (demanda, discurso, palavra de ordem, líder) que dariam coerência à cadeia, imbuindo-a de um senso de totalidade, ou um significante vazio, nos termos lacanianos recuperados por Laclau, é preciso relembrar o caráter recorrente que o populismo assume, no chamado Sul do mundo. As palavras - e ideologias, não nos esqueçamos - retornam repaginadas, 
mas mantêm sua essência tão presente no imaginário latino-americano e brasileiro, conforme Chaui: família, fé, retorno ao Paraíso e à ordem etc.

A chave, para a pensadora, está na dimensão psicanalítica do retorno do mito, a lógica do que é velho retornando como novo. No caso brasileiro, a já citada questão da volta ao Éden e da divinização ou satanização da figura política se repete: é um elemento central com nomes novos. Em suma, um fluxo político em eterno retorno do mesmo. O significante vazio seria, por isso, náo o fim do processo populista, como a leitura tradicionalmente feita sobre Laclau aponta, ou seja, a cristalização do processo até que o fluxo provoque mudanças no tecido socioinstitucional, mas seu início, pela existência a priori de um espaço estranho e impossível de ser preenchido no imaginário político de populaçóes inteiras, no Cone Sul, a partir de suas experiências concretas?

O próprio Laclau irá apontar posteriormente a insuficiência da separação rígida esboçada pelo uso anterior, em sua teoria, do conceito dos significantes vazios $^{12}$ como delimitadores dos campos dicotômicos estáveis de "nós X eles", os quais acabariam por restringir a possibilidade da multiplicidade - assim como obscurecer nossa visão a respeito do risco do sequestro das demandas por atores políticos autoritários:

Nosso modelo de significantes vazios. Chegou o momento de eliminá-lo. Até agora presumimos que cada demanda não atendida pode incorporarse à cadeia de equivalência que é constitutiva do campo popular [...]. Enquanto as demandas individuais são reforçadas por meio de sua inscrição de equivalência, a cadeia como um todo desenvolve uma lógica própria, que pode levar a um sacrifício ou a uma traiçáo dos objetivos dos elos individuais. (LACLAU, 2013, p. 208, grifo nosso).

O modo (ou modos) de vida populista, portanto, pode ser entendido como a relação possível entre tais fatores. Isso não quer dizer que, aqui no Brasil ou na América Latina, somente exista esse modo de vida, mas que este tem um significativo peso na produção de um pensamento e de um conjunto de práticas na sociedade (o que abarcaria, por exemplo, a produçáo intelectual e cultural) que ecoa, à sua forma, tais elementos providencialistas e messiânicos - ou a disputa de significado destes, da poesia de Olavo Bilac à busca por alternativas políticosociais embebidas na ideia da redenção dos oprimidos, como em Canudos, ou

\footnotetext{
${ }^{12}$ Laclau propóe a ideia dos significantes flutuantes, nos quais se dá um deslocamento dos significados possíveis de um termo (p. ex.: "povo"), que gerará uma disputa de significaçóes envolvidas nesse termo. Isso seria uma alternativa para resolver o fato de que, na prática, há momentos nos quais a fronteira dicotômica nós $X$ eles se desfaz.
} 
do resgate neorousseauniano por uma vida mais simples, paradisíaca, de retorno à Terra. Esse caráter flutuante do processo populista é um dos principais pilares teóricos trazidos à discussão por Chaui, e que não pareciam encontrar diálogo com a interpretaçáo corrente da teoria laclauniana.

Vale salientar que a postura salvacionista não é, necessariamente, desejada apenas pelos crentes na divindade judaico-cristá ou em qualquer outra que contenha certo nível de sincretismo com essa tradição. A ideia de buscar em elementos extramundo, no sobrenatural, no utópico, do originário ao cósmico e epistêmico-cosmológico, as chaves para a vida nessa sociedade e, que por meio da ação de tais elementos, a nossa realidade fática seria redimida em algum nível, notadamente político, é deveras sedutora. Trata-se aqui de uma disposição pessoal e cultural, ou de um ethos, o qual tem em si o elemento salvacionista que estaria entranhado nas formas de pensamento, reflexão e discurso cotidianas, políticas, econômicas e culturais. É singular observar que essa postura opera de modo simultaneamente transcendente (pela projeção/ desejo de um futuro paradisíaco que resgataria, em algum nível, a ideia do Éden ou da vida em comunidade antes da chegada do invasor) e imanente (pois é mobilizada a partir das contradiçóes que perpassam a sociedade, muitas vezes em função de eventos singulares que operam como aglutinadores de demandas diversas reprimidas nos agentes sociais) ao próprio discurso que estruturaria a prática populista.

Ainda que Laclau pense o populismo como uma questão discursiva, que, como tal, operaria para além das particularidades de uma formação social determinada, é preciso considerar, adotando uma perspectiva dialógica ${ }^{13}$, que a formação do próprio discurso dificilmente pode ser isolada do tecido social no qual esse discurso opera. Não é possível pensar que uma demanda cuja solução seja negada a um segmento social - o processo da formaçáo dinâmica de equivalências - seja somente abstrata ou discursiva. A demanda é gerada por um evento material que se imbrica à própria forma e verbalização da reivindicação.

\footnotetext{
${ }^{13}$ Se o discurso é, para Laclau e Mouffe, relacionado às práticas articulatórias, essa posição implica a rejeição da divisão entre discursivo e náo discursivo, o que traria consequências severas ou até a impossibilidade da definição de certos conceitos e ideias, como sociedade, sujeito, individualidade ou pessoa. Comungamos, aqui, da visão dialógica de Bakthin e Volochinov de que sujeitos, discursos e individualidades estão em perpétuo entrecruzamento e diálogo. O conflito constante entre esses fatores é fruto e causa do próprio tecido social onde se dão, não sendo possível dissociar (e não se trata aqui de determinismo, porém, de imbricação) decisões e atos de fala e ação dos contextos sócio-históricos onde são tomadas. Podemos afirmar que ocorre um processo dialético entre o sujeito e o social, ou entre a consciência individual e as relaçôes sociais.
} 
O significante vazio laclauniano, agora forçosamente perpassado por elementos constitutivos da sociedade, poderia, por conseguinte, ser provocativamente denominado, em um prisma Chauiniano, como a busca por um deus ausente, ou o locus no qual ocorre a projeção dos desejos mutáveis daqueles que o cultuam (ou seja, das demandas abstratas que se aglutinam nas palavras de ordem e nas pulsóes políticas), em um horizonte utópico de transformação da sociedade. Porém, esse horizonte sempre voltaria seus olhos para um passado idealizado, o retorno a um tempo sem sofrimento e angústia.

Pensando no Brasil, esse passado é um tempo quando o verde das florestas, o ouro do amarelo, o azul do céu e o branco da paz e da fé embrulham uma sociedade, que, embora tenha reconhecido sua origem conflituosa e opressora, poderia estabelecer um horizonte de funcionamento somente com rearranjos de suas forças, discursos e elementos formativos internos. Supor que, no nosso caso, fatores estritamente racionais orientam a produção e a aglutinação das demandas (ou mesmo que os fatores emocionais mobilizados poderiam, com seu atendimento institucional, permanecer em suspenso) seria subestimar as pulsóes conflituosas e violentas que atravessam, de cima a baixo, a constituição das relações sociais do "povo" brasileiro.

MAESO, B. E. A. In search of absent gods: the populist way of life in Laclau's and Chaui's point of view. Trans/form/ação, Marília, v. 44, n. 4, p. 49-72, Out./Dez., 2021.

\begin{abstract}
Understanding Latin-American politics implicates in defining its peculiarities regarding political forms amiss considered more developed by hegemonic central nations. A key concept for this process is that of populism. According to Ernesto Laclau, it can be defined as a political technique in which multiple social demands crystallize tentatively in slogans or in the figure of a leader, not depending on ideological alignment. On the other hand, Marilena Chaui identifies a concrete affinity between populist practices and social issues in a society, focusing on the so-called "founding myth" of Brazilian society and its prevalence in the imaginary. This article presents similarities and differences between forms of analysis of Latin-American politics by the aforementioned authors in order to trigger answers to questions such as: why does populism seem to fit so perfectly to Southern Hemisphere realities? Would it be more than a government practice system, but a way of life that is pervasive in political, economic, social and cultural institutions in Latin-American communities? To which extent the search for political and intellectual alternatives to the false messiah embodied in the populist leader is not resorting to the messianic logic that it is suposed to counter?
\end{abstract}

Keywords: Latin America. Brazil. Laclau. Chaui. Populism. 


\section{REFERÊNCIAS}

CHAUI, Marilena de Souza. Raízes teológicas do populismo no Brasil: teocracia dos dominantes, messianismo dos dominados. In: DAGNINO, E. (org.). Anos 90: Política e Sociedade No Brasil. São Paulo: Brasiliense, 1994.

CHAUI, Marilena de Souza. Espinosa: uma filosofia da Liberdade. Sáo Paulo: Moderna, 2003.

CHAUI, Marilena de Souza. Sobre o Populismo no Brasil. Conferência. In: COLÓQUIO INTERNACIONAL CLAUDE LEFORT: a invenção democrática hoje, 16 out. 2015. São Paulo. Anais [...], São Paulo: FFLCH/USP, 2015.

GOMEZ, Alvaro. Una discreta diferenciación entre la política y lo politico y su incidência sobre la educación en cuanto a la socialización política. Reflexión Política, v. 5, n. 9, 2003. Disponível em: https://revistas.unab.edu.co/index.php/reflexion/article/ view/749. Acesso em: 10 jun. 2021.

LACLAU, Ernesto. Populismo: ¿qué nos dice el nombre? In: PANIZZA, Francisco (org.). El Populismo como espejo de la democracia. Buenos Aires: FCE, 2009. p. 51-70.

LACLAU, Ernesto. Emancipaçáo e diferença. Rio de Janeiro: EdUERJ, 2011.

LACLAU, Ernesto. A Razáo Populista. São Paulo: Três Estrelas, 2013.

PEREIRA, Gilberto Braga; SANCHIS, Isabelle Paiva; MOREIRA, Lecy Rodrigues. Sujeito, Sociedade e Discurso. Arq. bras. psicol., Rio de Janeiro , v. 62, n. 2, p. 2-13, 2010. Disponível em: http://pepsic.bvsalud.org/scielo.php?script=sci_ arttext\&pid=S1809-52672010000200002\&lng=pt\&nrm=iso. Acesso em: 04 mar. 2021.

PINTO, Céli. Ernesto Laclau: da Democracia Radical ao Populismo. Revista e-Legis, Brasília, n. 24, p. 22-38, set./dez. 2017.

RETAMOZO, Martín, La teoria del populismo de Ernesto Laclau: una introducción. Estudios Politicos, novena época, n. 41, p. 157-184, maio/ago. 2017.

SANTOS, Samuel, A revisão do conceito de populismo por Ernesto Laclau: estratégias para a criação de um povo. Teoria \& Pesquisa - Revista de Ciência Política, v. 24, n. 2 , p. 144-148, jul./dez. 2015.

SIVIERO, José Marcelo. Populismo segundo Marilena Chaui: mito fundador e degradação da temporalidade. Comunicação. In: CICLO DE ESTUDOS SOBRE POPULISMO. GRUPO DE ESTUDOS ESPINOSANOS. 15 out. 2019, São Paulo. Anais [...], São Paulo: FFLCH/USP, 15 out. 2019.

Recebido: 19/7/2020

Aceito: 03/5/2021 